\title{
NAB2/STAT6 Fusion Gene
}

National Cancer Institute

\section{Source}

National Cancer Institute. NAB2/STAT6 Fusion Gene. NCI Thesaurus. Code C122819.

A fusion gene that results from a chromosomal rearrangement involving 12q13.3 and 12 q13 which fuses the first 6 exons of the NAB2 gene in frame with exon 3,17, or 18 of the STAT 6 gene. This fusion is associated with solitary fibrous tumors. 